\title{
Article
}

\section{Alum Addition Triggers Hypoxia in an Engineered Pit Lake}

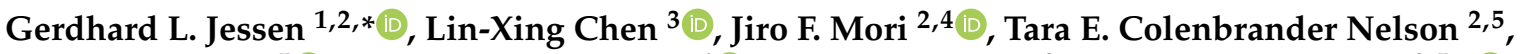 \\ Gregory F. Slater ${ }^{5} \mathbb{D}$, Matthew B. J. Lindsay ${ }^{6} \mathbb{D}$, Jillian F. Banfield ${ }^{3}$ and Lesley A. Warren ${ }^{2,5, * \mathbb{C}}$
}

1 Instituto de Ciencias Marinas y Limnológicas, Universidad Austral de Chile, Valdivia 5090000, Chile

2 Department of Civil and Mineral Engineering, University of Toronto, Toronto, ON M5S 1A4, Canada; morij@yokohama-cu.ac.jp (J.F.M.); tara.nelson@utoronto.ca (T.E.C.N.)

3 Department of Earth and Planetary Science, University of California, Berkeley, CA 94706, USA; linxingchen@berkeley.edu (L.-X.C.); jbanfield@berkeley.edu (J.F.B.)

4 Graduate School of Nanobioscience, Yokohama City University, Yokohama 236-0027, Japan

5 School of Earth, Environment and Society, McMaster University, Hamilton, ON L8S 4L8, Canada; gslater@mcmaster.ca

6 Department of Geological Sciences, University of Saskatchewan, Saskatoon, SK S7N 5E2, Canada; matt.lindsay@usask.ca

* Correspondence: gerdhard.jessen@uach.cl (G.L.J.); lesley.warren@utoronto.ca (L.A.W.)

check for

updates

Citation: Jessen, G.L.; Chen, L.-X.;

Mori, J.F.; Nelson, T.E.C.; Slater, G.F.; Lindsay, M.B.J.; Banfield, J.F.; Warren,

L.A. Alum Addition Triggers

Hypoxia in an Engineered Pit Lake.

Microorganisms 2022, 10, 510.

https://doi.org/10.3390/

microorganisms 10030510

Academic Editors: Julia M. Foght and Tariq Siddique

Received: 11 January 2022

Accepted: 11 February 2022

Published: 26 February 2022

Publisher's Note: MDPI stays neutral with regard to jurisdictional claims in published maps and institutional affiliations.

Copyright: (c) 2022 by the authors. Licensee MDPI, Basel, Switzerland. This article is an open access article distributed under the terms and conditions of the Creative Commons Attribution (CC BY) license (https:// creativecommons.org/licenses/by/ $4.0 /)$.

\begin{abstract}
Here, we examine the geobiological response to a whole-lake alum (aluminum sulfate) treatment (2016) of Base Mine Lake (BML), the first pilot-scale pit lake established in the Alberta oil sands region. The rationale for trialing this management amendment was based on its successful use to reduce internal phosphorus loading to eutrophying lakes. Modest increases in water cap epilimnetic oxygen concentrations, associated with increased Secchi depths and chlorophyll-a concentrations, were co-incident with anoxic waters immediately above the fluid fine tailings (FFT) layer post alum. Decreased water cap nitrate and detectable sulfide concentrations, as well as increased hypolimnetic phospholipid fatty acid abundances, signaled greater anaerobic heterotrophic activity. Shifts in microbial community to groups associated with greater organic carbon degradation (i.e., SAR11-LD12 subclade) and the SRB group Desulfuromonodales emerged post alum and the loss of specialist groups associated with carbon-limited, ammonia-rich restricted niches (i.e., MBAE14) also occurred. Alum treatment resulted in additional oxygen consumption associated with increased autochthonous carbon production, watercap anoxia and sulfide generation, which further exacerbate oxygen consumption associated with on-going FFT mobilized reductants. The results illustrate the importance of understanding the broader biogeochemical implications of adaptive management interventions to avoid unanticipated outcomes that pose greater risks and improve tailings reclamation for oil sands operations and, more broadly, the global mining sector.
\end{abstract}

Keywords: pit lakes; oil sands; tailing reclamation; hydrocarbon mining; ecological succession; aquatic microbiology

\section{Introduction}

Large volumes of fluid fine tailings (FFT) produced during bitumen extraction create significant challenges for mine reclamation in the Alberta oil sands region (AOSR) of northern Alberta, Canada. These tailings are initially composed of process-affected water (65-75 wt.\%), fine-grained solids (25-35 wt.\%), and residual petroleum hydrocarbons $(<5 \mathrm{wt} . \%)$. Oil sands process-affected water (OSPW) is characterized by elevated concentrations of dissolved salts, $\mathrm{NH}_{4}{ }^{+}, \mathrm{VH}_{2} \mathrm{~S}$, and detectable concentrations of various organics derived from oil sand deposits and the bitumen extraction process [1,2]. Elevated $\mathrm{CH}_{4}$ concentrations within FFT deposits result from the methanogenic degradation of fugitive diluent hydrocarbons and, to a lesser extent, residual bitumen [3-5]. Post-depositional settlement and dewatering produces a free water layer that gradually deepens with time. 
Slow pore water release coupled with growing production mean the total FFT inventory has grown to over 1.2 billion $\mathrm{m}^{3}$ across the AOSR [6].

Regulations aimed at promoting progressive reclamation and curbing inventory growth have accelerated the development of various FFT treatment and reclamation strategies [6-8]. Pit lakes (PL) are a key reclamation strategy being developed at oil sands mines [7]. These mine closure landforms, which are established in exhausted mine pits, are being developed for the reclamation of FFT, treated FFT, and OSPW [9-11]. Water-capped tailings technology (WCCT), i.e., PL, involves permanent FFT storage below a relatively shallow water cap initially dominated by OSPW [6]. Although water quality improvements driven by freshwater inputs and in situ biogeochemical processes are anticipated, many uncertainties concerning the long-term viability WCTT require investigation. In particular, PL need to maintain an oxygenated zone that can support biota and ecological function [2,12].

Extensive research focused on oil sands tailings ponds suggests that suspended finegrained solids and oxygen-consuming constituents (OCC), including $\mathrm{NH}_{4}{ }^{+}, \sum \mathrm{H}_{2} \mathrm{~S}, \mathrm{CH}_{4}$ and other organics, derived from FFT could inhibit the development of a persistent oxic zone within the upper water cap of PL supporting WCTT. Permanent anoxia within the free water layer of these tailings ponds results from extensive $\mathrm{O}_{2}$ consumption associated with high levels of microbial activity [3]. High turbidity resulting from the slow settlement of fine-grained FFT-derived particles and/or suspended solids contributions from oil sands process water (OSPW) within the water cap may also limit primary production and thus biological $\mathrm{O}_{2}$ production [13]. Research into these and other aspects of WCCT has largely focused on Base Mine Lake (BML), which was the first full-scale PL developed in the AOSR.

Early developmental stage investigation of the BML summer thermally stratified water cap three years post commissioning $[2,12,14]$ identified that $\mathrm{O}_{2}$ concentrations decreased with depth and were always less than 100\% saturated (surface August epilimnetic upper water cap oxygen concentrations averaged $\sim 156 \mu \mathrm{M}$ in 2015 and $\sim 188 \mu \mathrm{M}$ in 2016 [12] in the top portion of the water cap during peak summer stratification periods (i.e., where photosynthesis would be most likely to occur)). These results are consistent with other studies that suggested photosynthetic activity was impaired in this early stage due to a lack of water clarity [15] and/or associated with periodic lake surface hydrocarbon sheens [16]. However, both Risacher et al. [12] and Arriaga et al. [2] revealed low but persistent $\mathrm{O}_{2}$ concentrations within $\sim 2-3 \mathrm{~m}$ of the FFT water interface (FWI), i.e., $<10 \mu \mathrm{M}$ or $0.25 \mathrm{mg} \mathrm{L}^{-1}$ throughout the summer; oxygen consumption driven by mobilized reductants from the underlying FFT was not sufficient to cause anoxia.

In the fall of 2016, a whole lake alum (aluminum sulfate) addition trial was implemented to improve the clarity of the BML water cap, in aid of promoting greater primary productivity and increased oxygen concentrations [17]. Alum forms Al hydroxide flocs upon contact with water that can collect suspended particulates and sorb dissolved compounds as they settle out of the water column [18]. The rationale for trialing this management amendment was based on its successful use around the world to reduce internal phosphorus loading to eutrophying lakes and to clarify drinking water in water treatment plants, resulting in increased oxygen concentrations, and to clarify drinking water in water treatment plants [19-24].

However, the proposed BML alum addition was also likely to be a major disturbance impacting the water cap and potentially the FFT water interface (FWI) microbial communities, either through the stripping of water cap microbes associated with alum floc particle settling out, and/or changes to water cap ecological niches, which could affect BML water cap biogeochemical cycling and oxygen outcomes. Disturbances, whether alum amendments to soils or eutrophying lakes $[25,26]$, or other perturbations (i.e., changes in soil use, or altered wet-dry cycles simulating climate change effects; $[27,28]$ ) have been shown to change microbial community structure, function, and thus ecological outcomes. For instance, soil microbial communities have been shown in both field and in micro/mesocosm experiments to exhibit long-term changes in their structure following a disturbance [29,30]. 
Thus, investigation of the effects of alum addition on the microbial ecology and biogeochemical cycling in engineered ecosystems such as PL, which differ in their biogeochemical characteristics compared with more natural contexts, is vital to understanding the key processes affecting water cap oxygen outcomes. As a further 23 pit lakes are currently planned in the AOSR [2], this whole lake alum amendment provides a unique opportunity to inform the development of models that forecast processes and outcomes in these engineered contexts, as well as contributing to the understanding of aquatic systems undergoing disturbance through the characterization of microbial adaptation and system responses to this major perturbation. Here, our objectives were to identify changes in: (1) microbial community structure and function, (2) biogeochemical cycling, and (3) observed water cap $\mathrm{O}_{2}$ concentrations, through integrated geochemical and microbiological analyses of peak summer stratified, depth-dependent water samples collected pre and post alum addition.

\section{Materials and Methods}

\subsection{Site Description}

BML has now been described in several studies $[2,12,15,16,31]$. Briefly, BML $\left(57^{\circ} 1^{\prime} \mathrm{N}\right.$, $111^{\circ} 37^{\prime} \mathrm{W}$, elevation $308 \mathrm{~m}$, surface area $7.8 \mathrm{~km}^{2}$ ) was built in a mined-out oil sands pit at the Syncrude Canada Mildred Lake mine near Fort McMurray, AB Canada (Figure 1). Originally BML was a tailings impoundment that received FFT inputs from 1994 to 2012. The thickness of the FFT in 2012 was $45 \mathrm{~m}$ with a 3-5 m dominantly OSPW water cap on top. In November 2012, BML was disconnected from tailings operations, and freshwater from a nearby natural lake was added to increase the water depth to a level sufficient to prevent wind-wave-induced erosion of the underlying FFT material. Since 2012, with the addition of the freshwater and the on-going dewatering and consolidation of the underlying FFT, BML's water cap has increased in depth from $~ 8-9 \mathrm{~m}$ in 2012 to $10-11 \mathrm{~m}$ by 2018 . In the fall of 2016, a whole lake addition of alum $\left(3 \mathrm{CaAl}_{2}\left(\mathrm{SO}_{4}\right)_{3} 14.3 \mathrm{H}_{2} \mathrm{O}\right)$ to the BML water cap was made to promote clarity and encourage consolidation of the suspended solids, contributing to high turbidity within the water cap [17].
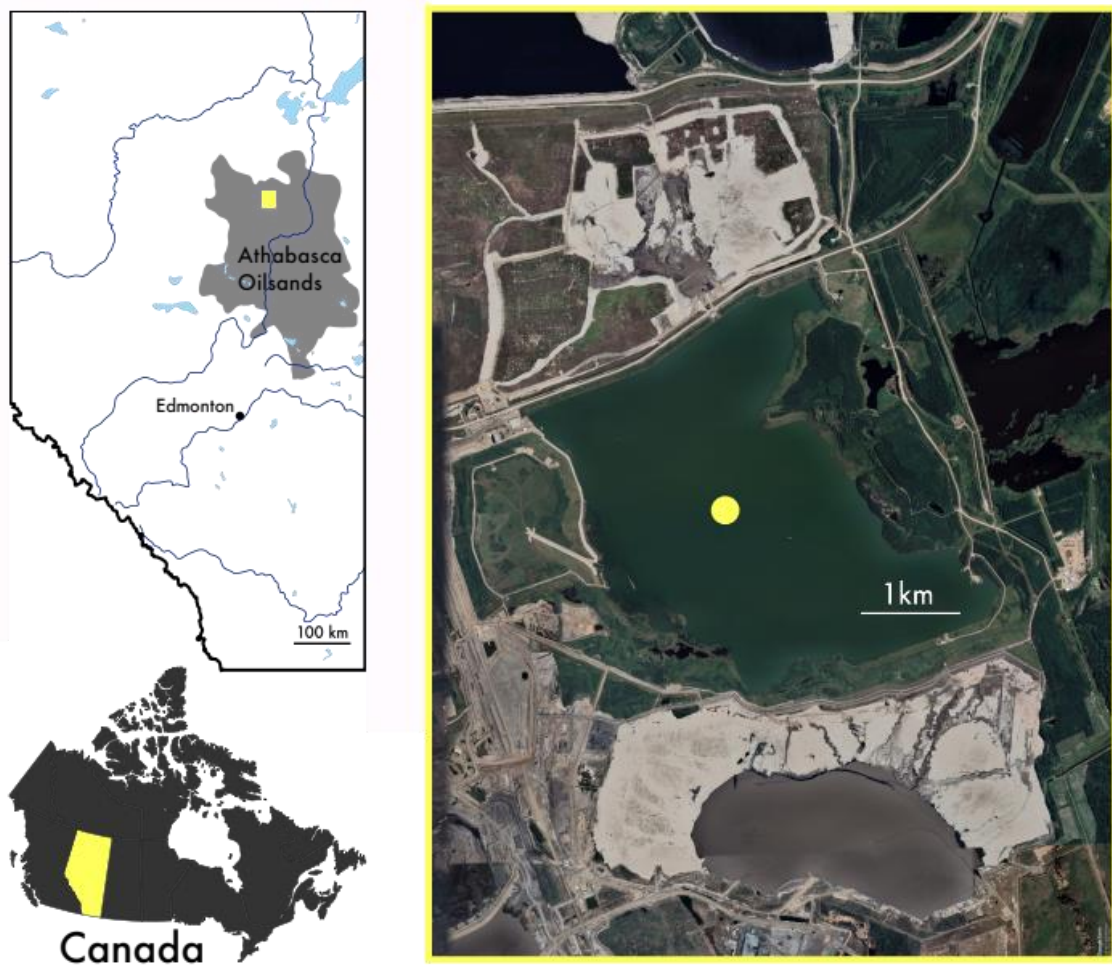

Figure 1. Location of Athabasca Oilsands region (grey) in Alberta, Canada. Aerial photo of Base Mine Lake (right panel) depicting sampling station (yellow dot). 


\subsection{Sampling Strategy}

Sampling campaigns were carried out on BML for three summers during maximum thermal stratification (August 2016-August 2018). Methods and sampling protocols have been described elsewhere $[2,12,14]$. Briefly, a physicochemical profile of the BML water cap (temperature, $\mathrm{pH}$, oxygen, specific conductivity, oxidation reduction potential (ORP)) was conducted using a YSI Professional Plus 6-Series Sonde (YSI Incorporated, Yellow Springs, $\mathrm{OH}, \mathrm{USA}$ ). Water samples were collected for both geochemical and microbiological characterization. Bulk water was retrieved in a 6.2 L Van Dorn bottle (Wilco, model Beta ${ }^{\circledR}$, Wildco, Yulee, FL, USA), while FFT was sampled using a custom-built fixed interval sampler as described in Mori et al. [14] and Dompierre et al. [32].

\subsection{Geochemical Analyses}

$\mathrm{CH}_{4}$, and concentrations of dissolved $(<0.45 \mu \mathrm{m})$ aqueous species of $\mathrm{NH}_{4}{ }^{+}, \mathrm{NO}_{2}{ }^{-}, \mathrm{NO}_{3}{ }^{-}$, $\Sigma \mathrm{H}_{2} \mathrm{~S}$, and $\mathrm{SO}_{4}{ }^{2-}$, were analyzed as described in Risacher et al. [13] and Arriaga et al. [2]. Briefly, $\left[\Sigma \mathrm{H}_{2} \mathrm{~S}\right]$ was analyzed via the methylene blue method directly after sampling using a $\mathrm{HACH}$ portable spectrophotometer (Hach DR/2800 spectrophotometer, HACH Company, Loveland, CO, USA). Dissolved methane was analyzed on an SRI GC (model 8610C, SRI Instruments, Torrance, CA, USA) equipped with a $1 \mathrm{~m}$ silica gel column and a flame ionization detector. $\mathrm{SO}_{4}{ }^{2-}$ and nitrogen species were analyzed spectrophotometrically following HACH DR/2800 spectrophotometer standard methods (HACH Company, Loveland, CO, USA). Bulk carbon, i.e., total organic carbon (TOC) and dissolved organic carbon (DOC), was analyzed as described in Whaley-Martin et al. [33]. In summary, frozen samples were thawed, filtered (for DOC only) and analyzed using a Shimadzu TOC-L (Shimadzu Precision Instruments, Kyoto, Japan). Organic carbon values were determined by subtracting the concentration of inorganic carbon from the total carbon values for that filter fraction (unfiltered, or $0.45 \mu \mathrm{m}$ filtered).

\subsection{DNA Extraction and Quantification}

Water and FFT cells were retrieved by filtering $~ 1.5 \mathrm{~L}$ water through $0.22 \mu \mathrm{m}$ RapidFlow sterile disposable filters (Thermo Fisher Scientific (Waltham, MA, USA)) and from ca. $50 \mathrm{~g}$ wet FFT, respectively, and stored at $-20{ }^{\circ} \mathrm{C}$ until DNA was extracted. DNA was extracted and purified from water column samples using the DNeasy PowerWater DNA Isolation Kit (Qiagen, Hilden, Germany), while ca. $0.5 \mathrm{~g}$ of each FFT sample was extracted using the FastDNA Spin Kit for Soil (MP Biomedical, Irvine, CA, USA). DNA concentration and quality were confirmed with a Qubit 2.0 Fluorometer (Thermo Fisher Scientific, Waltham, MA, USA) using a Qubit High-Sensitivity dsDNA Assay Kit (Thermo Fisher Scientific, Waltham, MA, USA), and DNA quality was assessed using an Epoch Microplate Spectrophotometer with Take3 plate (BioTek, Winooski, VT, USA).

\subsection{Amplicon Sequencing}

The same set of primers and the variable region of the 16S rRNA gene were used to characterize the microbial community structure in both water and FFT samples. The primer set 515f (5'-GTGYCAGCMGCCGCGGTAA-3') and 806r (5'-GGACTACNVGGGTWTCTAAT-3') was used to amplify the V4 region of the bacterial and archaeal 16S rRNA gene [34] following standard protocols of the Earth Microbiome Project $[35,36]$. In short, the PCR reaction protocol was conducted as follows: $50 \mathrm{ng}$ of DNA was denatured at $98{ }^{\circ} \mathrm{C}$ for $5 \mathrm{~min}$, followed by 35 cycles of denaturing at $98{ }^{\circ} \mathrm{C}$ for $30 \mathrm{~s}$, annealing at $50{ }^{\circ} \mathrm{C}$ for $30 \mathrm{~s}$ and extension at $72{ }^{\circ} \mathrm{C}$ for $30 \mathrm{~s}$, followed by final extension at $72{ }^{\circ} \mathrm{C}$ for $10 \mathrm{~min}$ [34]. Gel electrophoresis was used to check DNA products and positive amplicons were sequenced using the Illumina MiSeq platform. Water cap microbial DNA was sequenced at Farncombe Metagenomics Facility at McMaster University (Hamilton, ON, Canada) while DNA was extracted from FFT at the University of Calgary (Calgary, AB, Canada). The SequalPrep normalization kit (Thermo Fisher Scientific, Waltham, MA, USA) was used for amplicon normalization and sequenced with the Illumina MiSeq platform. Sequence reads were 
filtered and trimmed using Cutadapt (minimum quality score of 30 and a minimum read length $100 \mathrm{bp}$ ) [37]. Sequence variants were resolved using DADA2 [38] and merged to combine all information from separate Illumina runs. Chimeras and bimeras were removed along with sequences belonging to Eukaryota, chloroplasts and mitochondria. Taxonomy was assigned using the SILVA database version 132 [39]. Water column and FFT 16S rRNA gene amplicon sequences are deposited at NCBI under Bioproject PRJNA552483.

\subsection{Statistical Analyses}

Patterns of alpha and beta diversity were calculated from the relative abundance of sequence variants, whereas changes in community composition were explored using non-metric multidimensional scaling (NMDS; Bray-Curtis dissimilarities). Analysis of similarity (ANOSIM) was used to test differences between years and $p$-values corrected using Bonferroni's correction. Multivariate Redundancy Analyses (RDA) were performed to investigate the community response to the environment. Prior to the analyses, the complete physicochemical and geochemical characterization of the system was standardized (Z-scored) and checked for multicollinearity. After stepwise variable selection (based on the variance inflation factor; VIF), aluminum addition, temperature, oxygen, methane, nitrite and nitrate were retained. Multiple partial RDAs and variation partitioning (VP) analysis were used to assess significance and percentage of contribution to microbial variability. All statistical analyses were conducted following Buttigieg and Ramette [40] and Ramette [41] and using vegan R scripts [42] (version 3.6.2; www.R-project.org, accessed on 12 December 2019).

\section{Results and Discussion}

\subsection{Pre- and Post-Alum BML Water Cap Physico-Chemistry and Geochemistry}

No observable changes in thermal profiles were measured comparing pre-alum August 2016 thermal zonation to post-alum BML water cap stratification in August 2017 and August 2018 (Figure 2). For all three years, the August BML water cap exhibited maximum summer stratification and evidenced similar epilimnetic (0-4 m), metalimnetic (4-6.5 m) and hypolimnetic (6.5-10 m, FFT water interface (FWI)) zonation. In contrast, a modest increase (11-18\%) in maximum epilimnetic oxygen concentrations occurred post alum, increasing from $214 \mu \mathrm{M}$ in August of 2016, pre alum, to $238 \mu \mathrm{M}$ in 2017 and to $251 \mu \mathrm{M}$ in 2018 (Figure 2). However, lower hypolimnetic oxygen concentrations of the water above and immediately adjacent to the FWI, decreased from severe hypoxic $~ 10 \mu \mathrm{M}$ in 2016 pre alum, to anoxic over the lowest $1.75 \mathrm{~m}$ above FWI in 2017 and euxinic in 2018 post alum ([ $\left.\sum \mathrm{H}_{2} \mathrm{~S}\right]$ up to $9 \mu \mathrm{M}$, Figure 2, Table 1 ).

While epilimnetic oxygen concentrations increased 17\% between 2016 and 2018 (Table 2), carbon concentrations, whether total carbon (TC: filtered (TCF) or unfiltered (TCU)), TOC or DOC, evidenced successive decreases in both 2017 and 2018 post alum addition, whether considering averaged values over the entire water column or the hypolimnetic zone (Table 2$)$. The relative percent $(\Delta \%)$ decrease in absolute concentrations ranged from $25 \%$ for both averaged entire water cap or hypolimnion TCF and TCU, to $59-60 \%$ and $66-68 \%$ for averaged entire water cap or hypolimnion DOC and TOC concentrations (Table 2) from 2016 to 2018. In addition, the relative proportion of the total carbon occurring as either DOC or TOC also decreased for the averaged entire water cap or the hypolimnion by $23 \%, 28 \%, 31 \%$ and $36 \%$, respectively. The maximum dissolved methane concentrations observed at the FWI also decreased substantially (82-83\%) from $161 \mu \mathrm{M}$ in 2016 to $29 \mu \mathrm{M}$ (2017) and $27 \mu \mathrm{M}$ (2018; Table 1) post alum with upper water cap concentrations remaining low $(<1 \mu \mathrm{M})$ for all years. FWI ammonia concentrations also decreased post alum from a maximum observed in 2016 of $\sim 50 \mu \mathrm{M}$ to $\sim 40 \mu \mathrm{M}$ in 2017 and $\sim 29 \mu \mathrm{M}$ in 2018 (Table 1); however, upper water cap ammonia concentrations increased from $<10 \mu \mathrm{M}$ (2016), to $<20 \mu \mathrm{M}$ (2017), to $<30 \mu \mathrm{M}$ (2018; Table 1), while no observable changes in organic phosphorus were measured $\left(2.27 \pm 0.5 \mu \mathrm{g} \mathrm{L}{ }^{-1}\right.$, Table S1). The divergent responses of these two previously identified important OCC were shown to dominantly 
influence BML water cap oxygen concentrations pre alum [2,13], suggesting the post alum development of lower BML water cap euxinia reflects a more complex set of processes.

Table 1. Aqueous and FFT physico-and geochemical characterization of BML.

\begin{tabular}{|c|c|c|c|c|c|c|c|c|c|c|c|c|c|}
\hline Year & $\begin{array}{l}\text { Depth } \\
\text { [m] }\end{array}$ & $\begin{array}{c}\text { Oxygen } \\
(\mu \mathrm{M})\end{array}$ & $\begin{array}{c}\text { Temp } \\
\text { (C) }\end{array}$ & $\mathrm{pH}$ & $\begin{array}{c}\mathrm{EC} \\
\left(\mathrm{mScm}^{-1}\right)\end{array}$ & $\begin{array}{c}\text { TOC } \\
\left(\mathrm{mgL}^{-1}\right)\end{array}$ & $\begin{array}{c}\text { DOC } \\
\left(\mathrm{mgL}^{-1}\right)\end{array}$ & $\begin{array}{l}\text { Methane } \\
(\mu \mathrm{M})\end{array}$ & $\begin{array}{c}\text { Ammonia } \\
(\mu \mathrm{M})\end{array}$ & $\begin{array}{l}\text { Nitrite } \\
(\mu \mathrm{M})\end{array}$ & $\begin{array}{c}\text { Nitrate } \\
(\mu \mathrm{M})\end{array}$ & $\begin{array}{c}\text { Sulfate } \\
(\mu \mathrm{M})\end{array}$ & $\begin{array}{c}\text { Sulfide } \\
(\mu \mathrm{M})\end{array}$ \\
\hline 2016 & 0.00 & 214.2 & 20.8 & 8.2 & 2.82 & 99.9 & 87.7 & 0.6 & 9.9 & 1.5 & 38.8 & 2026.7 & 0.0 \\
\hline 2016 & 0.50 & 200.8 & 20.7 & 8.3 & 2.82 & & & & & & & & \\
\hline 2016 & 1.00 & 197.7 & 20.5 & 8.3 & 2.82 & & & & & & & & \\
\hline 2016 & 1.50 & 196.9 & 20.4 & 8.3 & 2.82 & 58.8 & 57.5 & 0.5 & 8.6 & 2.0 & 36.0 & 2212.1 & 0.0 \\
\hline 2016 & 2.00 & 194.7 & 20.3 & 8.3 & 2.82 & & & & & & & & \\
\hline 2016 & 2.50 & 194.0 & 20.3 & 8.3 & 2.82 & & & & & & & & \\
\hline 2016 & 3.00 & 192.5 & 20.2 & 8.3 & 2.82 & & & & & & & & \\
\hline 2016 & 3.50 & 187.7 & 20.0 & 8.3 & 2.82 & & & & & & & & \\
\hline 2016 & 4.00 & 179.0 & 19.8 & 8.3 & 2.82 & & & & & & & & \\
\hline 2016 & 4.25 & 167.9 & 19.5 & 8.3 & 2.82 & & & & 6.7 & 1.9 & 34.0 & 2280.9 & 0.0 \\
\hline 2016 & 4.50 & 156.7 & 19.3 & 8.2 & 2.82 & 58.4 & 58.3 & 0.4 & 10.4 & 2.3 & 39.4 & 1709.5 & 0.0 \\
\hline 2016 & 4.75 & 144.0 & 19.1 & 8.2 & 2.82 & & & & 8.1 & 1.4 & 39.4 & 2314.4 & 0.0 \\
\hline 2016 & 5.00 & 131.3 & 18.9 & 8.2 & 2.82 & & & & & & & & \\
\hline 2016 & 5.50 & 120.9 & 18.6 & 8.2 & 2.82 & & & 0.7 & 6.0 & 1.1 & 39.0 & 2333.8 & 0.0 \\
\hline 2016 & 6.00 & 68.6 & 17.5 & 8.1 & 2.84 & 60.7 & 60.9 & 0.6 & 6.2 & 6.2 & 47.2 & 2115.4 & 0.0 \\
\hline 2016 & 6.25 & 46.5 & 17.0 & 8.1 & 2.85 & & & & 7.5 & 1.6 & 31.4 & 1869.1 & 0.0 \\
\hline 2016 & 6.50 & 24.3 & 16.6 & 8.0 & 2.87 & & & 0.2 & 15.9 & 10.3 & 45.7 & 1824.1 & 0.0 \\
\hline 2016 & 7.00 & 13.9 & 15.6 & 8.0 & 2.88 & 61.0 & 59.0 & 11.1 & 22.1 & 5.0 & 43.4 & 2039.3 & 0.0 \\
\hline 2016 & 7.50 & 11.4 & 15.0 & 7.9 & 2.89 & & & 9.5 & 16.8 & 5.8 & 34.2 & 1802.5 & 0.0 \\
\hline 2016 & 8.00 & 10.5 & 14.5 & 7.9 & 2.90 & 94.5 & 87.5 & 39.0 & 27.9 & 4.7 & 12.8 & 2007.5 & 0.0 \\
\hline 2016 & 8.50 & 10.5 & 14.3 & 7.9 & 2.91 & & & & & & & & \\
\hline 2016 & 9.00 & 9.1 & 14.1 & 7.9 & 2.89 & & & 126.3 & 49.7 & 0.8 & 15.5 & 2049.8 & 0.0 \\
\hline 2016 & $(\mathrm{FFT})-0.05$ & 50.0 & & 8.1 & 2.96 & & 72.0 & $>1200$ & $>600$ & $<10$ & $<20$ & $<100$ & $>10$ \\
\hline 2017 & 0.00 & 238.2 & 20.9 & 8.3 & 2.79 & 54.8 & 48.2 & 0.8 & 16.9 & 4.7 & 48.9 & 2627.4 & 0.0 \\
\hline 2017 & 1.00 & 236.6 & 21.1 & 8.3 & 2.79 & & & & & & & & \\
\hline 2017 & 1.50 & 237.2 & 20.8 & 8.3 & 2.79 & 54.5 & 48.9 & 0.8 & 13.0 & 4.2 & 54.5 & 2685.6 & 0.0 \\
\hline 2017 & 2.00 & 236.6 & 21.0 & 8.3 & 2.79 & & & & & & & & \\
\hline 2017 & 3.00 & 235.8 & 20.7 & 8.3 & 2.79 & & & & & & & & \\
\hline 2017 & 4.00 & 234.7 & 20.9 & 8.3 & 2.79 & & & & & & & & \\
\hline 2017 & 4.50 & 234.5 & 20.5 & 8.3 & 2.78 & 53.8 & 49.8 & 1.0 & 17.2 & 4.5 & 55.1 & 2601.0 & 0.0 \\
\hline 2017 & 5.00 & 224.6 & 20.2 & 8.3 & 2.78 & & & & & & & & \\
\hline 2017 & 5.50 & 195.9 & 19.6 & 8.3 & 2.79 & 55.8 & & 0.8 & 16.5 & 4.3 & 52.3 & 2690.9 & 0.0 \\
\hline 2017 & 5.75 & 213.5 & 19.7 & 8.3 & 2.79 & & & & & & & & \\
\hline 2017 & 6.00 & 135.4 & 18.4 & 8.3 & 2.80 & & & & & & & & \\
\hline 2017 & 6.50 & 93.7 & 17.4 & 8.2 & 2.80 & 52.8 & 48.1 & 0.6 & 25.4 & 3.5 & 35.8 & 2606.3 & 0.0 \\
\hline 2017 & 7.00 & 59.1 & 16.8 & 8.2 & 2.80 & & & & & & & & \\
\hline 2017 & 7.25 & 48.1 & 16.3 & 8.1 & 2.80 & & & & & & & & \\
\hline 2017 & 7.50 & 16.5 & 15.8 & 8.1 & 2.80 & 54.3 & 49.5 & 0.7 & 31.3 & 2.6 & 22.5 & 2475.8 & 0.0 \\
\hline 2017 & 7.75 & 11.9 & 15.6 & 8.1 & 1.80 & 38.4 & 38.6 & 1.3 & 33.2 & 2.7 & 21.3 & 2559.5 & 0.0 \\
\hline 2017 & 8.00 & 1.0 & 15.1 & 8.1 & 2.80 & 50.3 & 48.9 & 3.1 & 34.0 & 2.3 & 14.7 & 2601.0 & 0.0 \\
\hline 2017 & 8.50 & 0.7 & 14.9 & 8.0 & 2.80 & & & & & & & & \\
\hline 2017 & 9.00 & 0.1 & 14.5 & 8.0 & 2.80 & & 52.1 & & & & & & \\
\hline 2017 & 9.50 & 0.0 & 14.1 & 8.0 & 2.80 & & & & & & & & \\
\hline 2017 & 9.75 & 0.0 & 14.3 & 8.0 & 2.81 & & 49.7 & 28.9 & 40.2 & 0.8 & 0.0 & 2579.8 & 0.0 \\
\hline 2017 & $(\mathrm{FFT})-0.08$ & $\begin{array}{ll}8 & 0.0\end{array}$ & & 7.8 & 3.08 & & 75.0 & $>1200$ & $>600$ & $<10$ & $<20$ & $<100$ & $>10$ \\
\hline 2018 & 0.00 & 251.6 & 20.9 & 8.3 & 2.53 & 32.5 & 32.0 & 0.3 & 16.4 & 1.2 & 0.0 & 2056.0 & 0.0 \\
\hline 2018 & 1.50 & 247.5 & 20.0 & 8.3 & 2.48 & 48.9 & 47.5 & 0.4 & 24.9 & 1.3 & 0.0 & 2064.8 & 0.0 \\
\hline 2018 & 4.00 & 227.8 & 18.2 & 8.2 & 2.41 & & & & & & & & \\
\hline 2018 & 4.50 & 214.4 & 17.6 & 8.2 & 2.34 & 48.6 & 44.9 & 0.4 & 21.7 & 1.4 & 0.0 & 2045.4 & 0.0 \\
\hline 2018 & 5.50 & 211.3 & 17.4 & 8.2 & 2.33 & & & & & & & & \\
\hline 2018 & 6.00 & 206.3 & 17.3 & 8.2 & 2.33 & & & & & & & & \\
\hline 2018 & 6.50 & 191.9 & 17.0 & 8.2 & 2.32 & & & & & & & & \\
\hline 2018 & 7.00 & 181.6 & 16.8 & 8.2 & 2.31 & & & & & & & & \\
\hline 2018 & 7.50 & 125.6 & 16.1 & 8.1 & 2.29 & 37.1 & 35.8 & 0.3 & 27.2 & 1.3 & 0.0 & 2096.6 & 0.0 \\
\hline 2018 & 7.75 & 68.8 & 15.3 & 8.1 & 2.27 & & & & & & & & \\
\hline 2018 & 8.00 & 35.9 & 14.9 & 8.0 & 2.22 & & & & & & & & \\
\hline 2018 & 8.50 & 0.3 & 13.4 & 8.0 & 2.20 & & & & & & & & \\
\hline 2018 & 8.75 & 0.0 & 13.2 & 8.0 & 2.19 & 51.6 & 49.4 & 6.4 & 41.5 & 1.0 & 0.0 & 2096.6 & 0.0 \\
\hline 2018 & 9.00 & 0.0 & 13.1 & 7.9 & 2.19 & & & & & & & & \\
\hline 2018 & 9.50 & 0.0 & 13.0 & 7.9 & 2.18 & & & 6.1 & & & & & \\
\hline 2018 & 9.75 & 0.0 & 12.9 & 7.9 & 2.18 & 52.2 & 43.0 & 13.6 & 34.6 & 0.9 & 0.0 & 2075.4 & 4.4 \\
\hline 2018 & 10.00 & 0.0 & 12.8 & 7.9 & 2.17 & & & & & & & & \\
\hline 2018 & 10.50 & 0.0 & 12.4 & 7.9 & 2.16 & 52.2 & 48.5 & 26.9 & 28.6 & 0.9 & 0.0 & 2029.6 & 9.0 \\
\hline
\end{tabular}



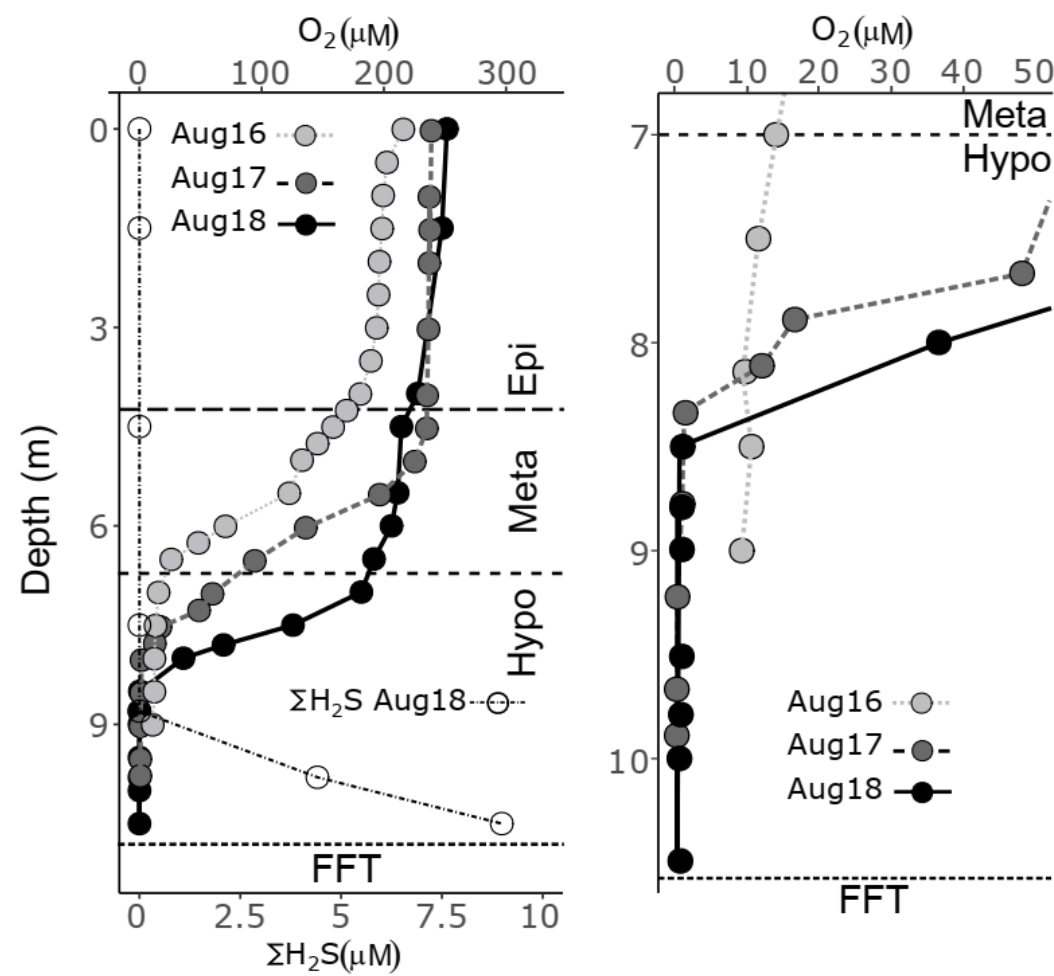

Figure 2. Water column (left) and bottom water (right) oxygen and sulfide concentrations for August 2016-2018 at BML.

Nitrate concentrations were highest in the upper waters in both 2016 (pre alum, $\sim 30-40 \mu \mathrm{M}$ ) and 2017 (1st year post alum, 50-55 $\mu \mathrm{M}$ ), decreasing towards the FWI (Table 1). However, while nitrate, along with oxygen, persisted to the FWI in 2016, it was below detection in the bottom anoxic meter of the BML water cap in 2017 and was completely non detectable throughout the water cap in 2018 (Table 1), indicating that a lack of nitrification and greater nitrate consumption alongside oxygen consumption were occurring and increasing year over year for the two years investigated, post alum. Concentrations of sulfate were orders of magnitude higher (2-3 mM) compared with other constituents throughout the water cap across all years (Table 1). Mean August water cap sulfate concentrations increased $27 \%$ from $2045 \mu \mathrm{M}$ (2016) to $2603 \mu \mathrm{M}$ in 2017, consistent with the addition of sulfate from alum. However, sulfate concentrations decreased in 2018 to pre-alum 2016 levels, averaging $2072 \mu \mathrm{M}$. This result suggests that beyond the ongoing settling of the FFT, anoxia enabled SRB presence and activity within the water cap, consistent with greater reductive metabolism occurring in BML post alum (Table 1). Furthermore, for the first time in 2018, detectable $\sum \mathrm{H}_{2} \mathrm{~S}$ occurred in the bottom anoxic waters of BML $(9 \mu \mathrm{M}$; Table 1) providing evidence of SRB activity. These geochemical results collectively indicate changes in microbial redox dynamics with greater overall reductive processes occurring in BML post alum addition.

\subsection{FFT Porewater Chemistry}

Porewater chemistry for the upper $0.5 \mathrm{~m}$ of FFT is summarized for August 2016 (pre alum) and July 2017 (post alum) in Table 1 and in more detail in Mori et al. [14]. Briefly, highly anaerobic conditions persisted in both years, as shown by high dissolved concentrations of ammonia $(>600 \mu \mathrm{M})$, methane $(>1200 \mu \mathrm{M})$, and $\sum \mathrm{H}_{2} \mathrm{~S}(>10 \mu \mathrm{M})$ that increased with depth in the upper FFT (Table 1, [14,43]). Sulfate concentrations decreased substantially $(<100 \mu \mathrm{M})$ over the same depth, representing a $90 \%$ decrease relative to the water cap [14,43]. Low sulfate concentrations coupled with elevated $\sum \mathrm{H}_{2} \mathrm{~S}$ concentrations suggest sulfate reduction activity occurring in the upper FFT, consistent with the apparent depletion of other, higher energy electron acceptors (i.e., nitrate, ferric iron) within the FFT 
porewater. Porewater DOC concentrations in the upper FFT increased slightly to $>6 \mu \mathrm{M}$ with depth below the FWI.

Table 2. Annual trends from August 2016 to August 2018 in the BML carbon pool in the entire water cap as well as in the hypolimnion and in epilimnetic oxygen concentrations $\left(\mathrm{TC}_{\mathrm{F}}\right.$, total carbon filtered $(0.45 \mu \mathrm{m}) ; \mathrm{TC}_{\mathrm{U}}$, total carbon unfiltered; TOC, total organic carbon; DOC, dissolved organic carbon; (av) $\mathrm{H}_{2} \mathrm{O}$ cap, averaged (av) value over entire depth profile; (av) hypolimnion, averaged value over hypolimnetic zone (>7.5 m); (av) epilimnion $\mathrm{O}_{2}$, averaged value of $0-4 \mathrm{~m}$ of BML water cap). Changes in year-to-year $(\Delta)$ concentrations of these carbon pools, as well as epilimnetic oxygen concentrations as concentration and $\%$ are also shown.

\begin{tabular}{|c|c|c|c|c|c|c|}
\hline & $\mathrm{TC}_{\mathrm{F}}$ & $\mathrm{TC}_{\mathrm{U}}$ & TOC & DOC & $\mathrm{TOC}^{\mathrm{TTC}} \mathrm{U}$ & $\mathrm{DOC}^{\mathrm{TTC}} \mathrm{F}_{\mathrm{F}}$ \\
\hline & $\mathrm{mg} \mathrm{L}^{-1}$ & $\mathrm{mg} \mathrm{L}^{-1}$ & $\mathrm{mg} \mathrm{L}^{-1}$ & $\mathrm{mg} \mathrm{L}^{-1}$ & $\%$ & $\%$ \\
\hline & \multicolumn{2}{|c|}{ (av) $\mathrm{H}_{2} \mathrm{O}$ cap } & \multicolumn{2}{|c|}{ (av) $\mathrm{H}_{2} \mathrm{O}$ cap } & \multicolumn{2}{|c|}{ (av) $\mathrm{H}_{2} \mathrm{O}$ cap } \\
\hline 2016 & 214 & 219.8 & 72.2 & 68.5 & 32 & 32 \\
\hline 2017 & 182.5 & 179.3 & 51.2 & 54.2 & 28 & 29 \\
\hline \multirow[t]{2}{*}{2018} & 172.5 & 176.1 & 45 & 43 & 25 & 26 \\
\hline & \multicolumn{2}{|c|}{ (av) hypolimnion } & \multicolumn{2}{|c|}{ (av) hypolimnion } & \multicolumn{2}{|c|}{ (av) hypolimnion } \\
\hline 2016 & 224.9 & 231.4 & 77.8 & 73.2 & 34 & 34 \\
\hline 2017 & 181.9 & 162.2 & 47.7 & 46.7 & 29 & 26 \\
\hline \multirow[t]{3}{*}{2018} & 180.6 & 185.7 & 46.3 & 44.2 & 25 & 26 \\
\hline & $\Delta \mathrm{TC}_{\mathrm{F}}(\%)$ & $\Delta \mathrm{TC}_{\mathrm{U}}(\%)$ & $\Delta \mathrm{TOC}(\%)$ & $\begin{array}{c}\Delta \text { DOC } \\
(\%)\end{array}$ & $\underset{(\%)}{\Delta \mathrm{TOC} / \mathrm{TC}_{\mathrm{U}}}$ & $\underset{(\%)}{\Delta \mathrm{DOC} / \mathrm{TC}_{\mathrm{F}}}$ \\
\hline & \multicolumn{6}{|c|}{$\Delta(\mathrm{av}) \mathrm{H}_{2} \mathrm{O}$ cap decrease } \\
\hline 2016-2017 & 15 & 18 & 29 & 21 & 13 & 9 \\
\hline 2017-2018 & 5 & 2 & 12 & 21 & 11 & 10 \\
\hline \multirow[t]{2}{*}{ 2016-2018 } & 24 & 25 & 60 & 59 & 28 & 23 \\
\hline & \multicolumn{6}{|c|}{$\Delta$ (av) hypolimnion decrease } \\
\hline 2016-2017 & 19 & 30 & 39 & 36 & 15 & 24 \\
\hline 2017-2018 & 1 & -14 & 3 & 5 & 14 & 0 \\
\hline \multirow[t]{3}{*}{ 2016-2018 } & 5 & 25 & 68 & 66 & 36 & 31 \\
\hline & \multicolumn{6}{|c|}{$\Delta$ (av) epilimnetic $\left(\mathrm{O}_{2}\right)$ increase } \\
\hline & $\begin{array}{c}\Delta\left(\mathrm{O}_{2}\right) \\
\mu \mathrm{M}\end{array}$ & $\begin{array}{c}\Delta\left(\mathrm{O}_{2}\right) \\
\mathrm{mg} \mathrm{L}^{-1}\end{array}$ & $\begin{array}{c}\Delta\left(\mathrm{O}_{2}\right) \\
\%\end{array}$ & & & \\
\hline 2016-2018 & 24 & 0.75 & 11 & & & \\
\hline 2016-2018 & 13 & 0.41 & 5 & & & \\
\hline 2016-2018 & 37 & 1.16 & 17 & & & \\
\hline
\end{tabular}

Porewater $\mathrm{CH}_{4}, \mathrm{NH}_{4}{ }^{+}$and $\sum \mathrm{H}_{2} \mathrm{~S}$ concentrations were generally consistent between 2016 and 2017 (Table 1), suggesting the effects of alum treatment on water chemistry did not extend below the FWI. These results are consistent with previous findings that the FFT microbial community structure exhibited greater variation with depth than over time $[14,43]$.

\subsection{Shifts in Microbial Community Structure through Time}

Evident changes in BML water cap microbial community structure occurred post alum addition (Figure 3A,B, Table S2), consistent with the collective observed geochemical shifts, suggesting greater e- acceptor consumption and the production of reduced metabolites. In 2017 and 2018, BML water cap microbial communities significantly increased in richness (i.e., a greater number of species, $\mathrm{F}(2,22)=3.6, p<0.05$; Tukey post hoc test, $p<0.05$ ); however, diversity significantly decreased (i.e., integrating both the number of species and the abundance of individuals within each species, $(\mathrm{F}(2,22)=9.1, p<0.01$; Tukey post hoc test, $p<0.01)$ ) suggesting the possible emergence of pioneer species after the 
alum addition. As Rönicke et al. [26] identified, studies that report on the long-term consequences of alum addition to the ecology of lakes are rare, despite the use of alum for the treatment of eutrophying systems for over 40 years. However, Lin et al. [44] identified no significant difference in rhizosphere community composition, but a significant difference in the abundance of the major taxa associated in experiments assessing $\mathrm{Al}$ addition to soil. Wang et al. [27] also showed abundance changes in carbon-fixing bacterial taxa in wetland soils associated with disturbance and reclamation, while Zhang et al. [28] identified that compositional changes in microbial communities occurred in soils associated with different tillage regimes, while diversity remained unchanged. In this latter study, they attributed the differences in abundances to changes observed in soil organic carbon fractions.
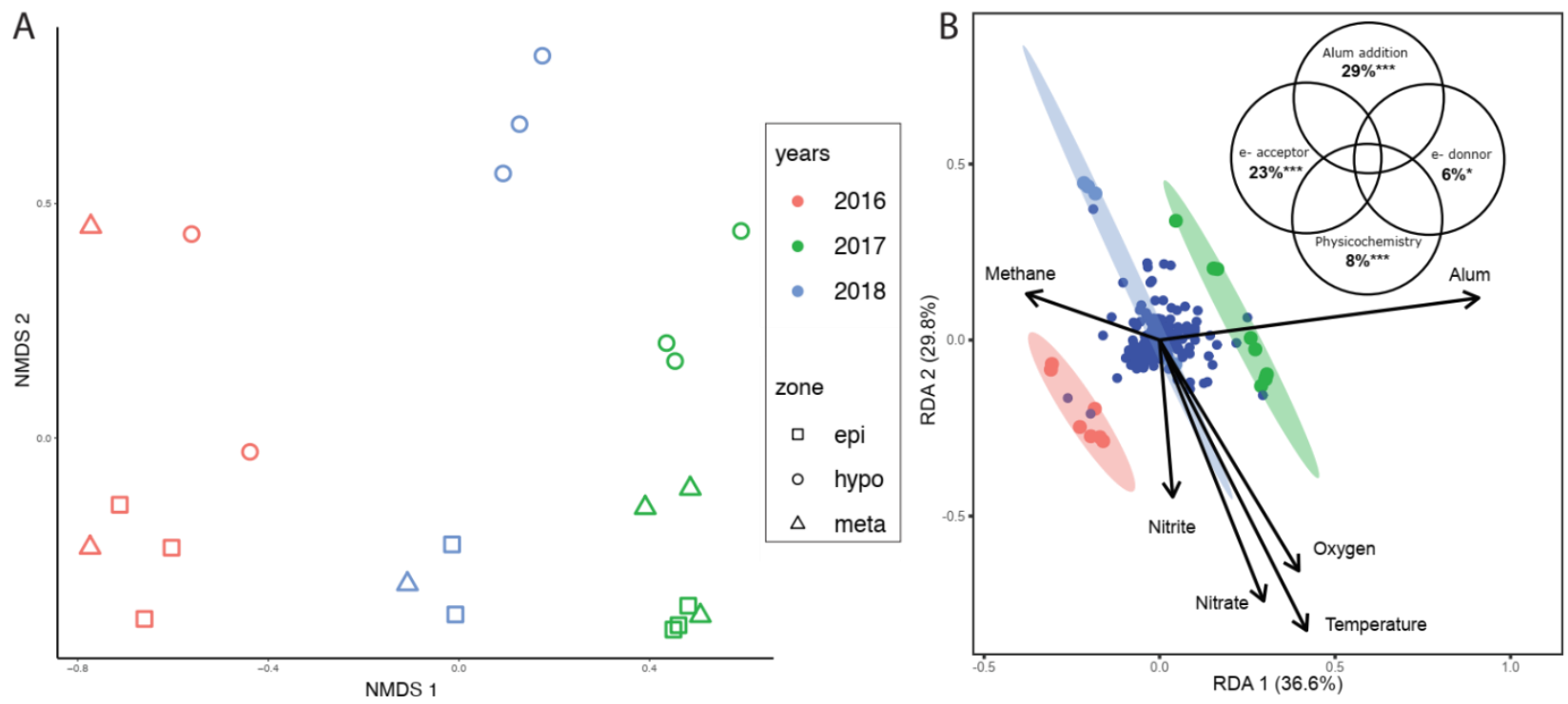

Figure 3. (A) Non-metric multidimensional scaling (NMDS) plot of samples at sequence variants level (based on Bray-Curtis dissimilarity from Illumina sequencing of 16S rRNA gene amplicons), depicting differences between microbial community structure among years (August 20162018) and stratifications zones at Base Mine Lake (stress = 0.11, ANOSIM; $\mathrm{R}=0.8-0.9, p<0.001$ ). (B) RDA ordination depicting microbial diversity (based on sequence variants) in relation to significant aqueous physico-chemistry and geochemistry. The Venn diagram shows the significant effect (\%) of physico-chemistry (temperature), e- acceptor (oxygen, nitrite and nitrate), e- donor (methane) and alum $\left(\mathrm{AlSO}_{4}{ }^{2-}\right)$ treatment on the bacterial diversity at BML $(p<0.001) .{ }^{* *} p<0.001,{ }^{*} p<0.03$.

Losses and gains in species diversity affect the ecological stability and sustainability of ecosystem services. Decreased diversity has been suggested to decrease ecological stability and a community's resistance to environmental change and rates of recovery from further disturbances [45]. A nonmetric multidimensional scaling (NMDS) ordination plot (based on Bray-Curtis distance matrix of amplicon sequence variants (ASVs)) indicated that these alum-associated BML microbial community differences were significant across all years, i.e., the 2nd year post alum, 2018, was also significantly different from 2017 (ANOSIM, Bonferroni corrected, $p<0.005$, Figure 3A). Indeed, alum addition was raised as the main factor structuring the microbial community, followed by oxygen, nitrite and nitrate $(p<0.001$, Figure $3 \mathrm{~B})$. This is consistent with a rapid response in the microbial community to the initial ecosystem perturbation and an on-going differentiation of the BML water cap microbial communities two years post alum addition.

Microbial redox and successional shifts are linked to shifts in diagenetic transformations, suggesting that changes in the quantity of specifically labile organic carbon occurred post alum. While decreases in TOC and DOC concentration were noted, the relatively unchanged dominating abundance and distribution of Burkholderiales, both in the water column and FFT, is consistent with the dominance of refractory carbon materials, as members 
are known for their effective utilization of numerous recalcitrant organic compounds [46] (Figure 4). In contrast, MBAE14, present in 2016 pre alum, vanished, while SAR11 (LD12 subclade) appeared in high abundance after alum addition (Figure 4). Members of the novel MBAE14 group inhabit a narrow habitat of ammonia-rich, oxygen- and labile organic matter-limited conditions that characterized BML up to 2016 [14]. In contrast, the aerobic chemo-organotrophic lifestyle of the SAR11 (LD12 subclade) [47] suggests their emergence post alum is linked to an increase in the quantity of higher quality (i.e., more accessible) organic matter. The occurrence of anoxia in the bottom waters post alum, along with the decreased concentrations of nitrate and sulfate and increased ammonia concentration in the BML water cap by 2018 especially (Table 1), are collectively consistent with greater heterotrophic activity. These results suggest that an important effect of the alum addition was to stimulate the generation of autochthonous organic carbon, i.e., phytoplankton, that could support greater heterotrophic activity. Similarly, Flavobacteriales (mainly comprising the genus Flavobacterium) were also ubiquitous across all three years, suggesting that this group, with its metabolic versatility and copiotrophic characteristics [48], may also adapt well to varying organic matter quality and availability and oxygen conditions.

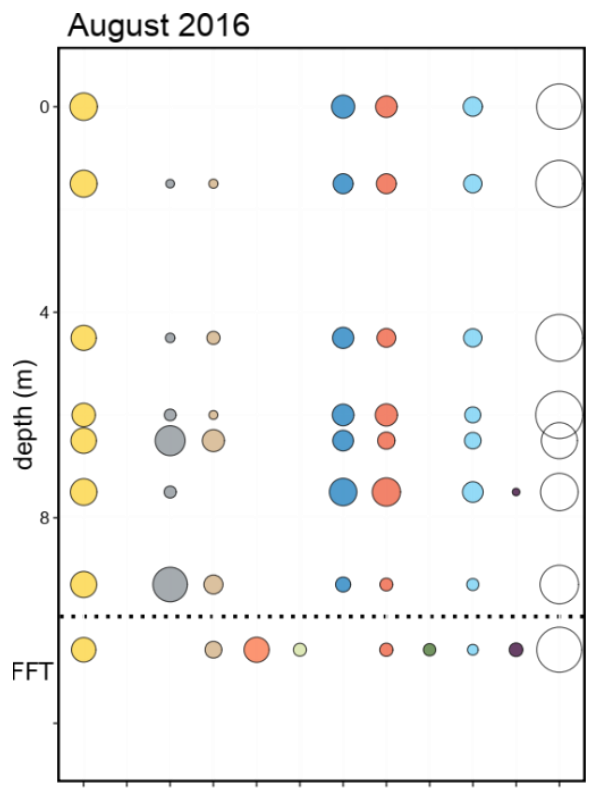

$\begin{array}{llll}\mathrm{O} & \text { Burkholderiales } & \bigcirc & \text { Frankiales } \\ \mathrm{O} & \text { SAR11(LD12subclade) } & \mathrm{O} & \text { Sphingobacteriales } \\ \mathrm{O} & \text { MBAE14 } & \bigcirc & \text { Bacteroidales } \\ \mathrm{O} & \text { Methylococcales } & \bigcirc & \text { Flavobacteriales } \\ \mathrm{O} & \text { Desulfobacterales } & \bigcirc & \text { Verrucomicrobiales } \\ \mathrm{O} & \text { Desulfuromonadales } & \mathrm{O} & \text { others }\end{array}$

August 2017

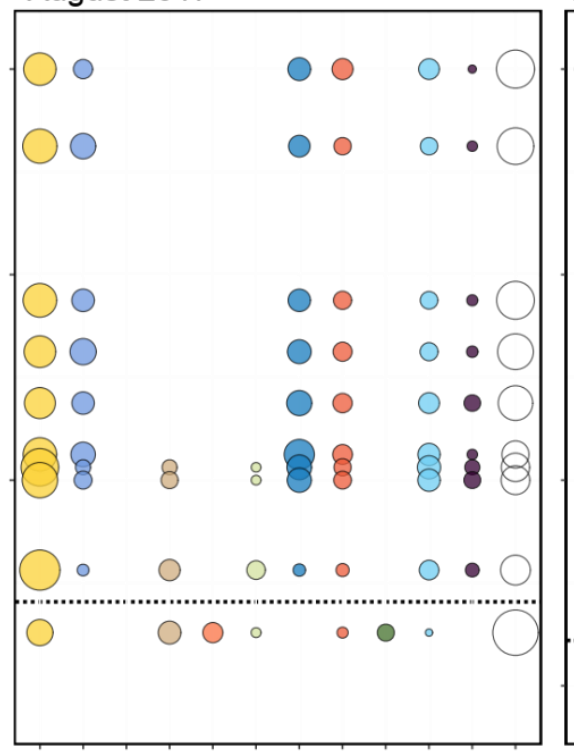

Relative Abundance

○ $\quad 0.03$

○ 0.15

○ 0.30

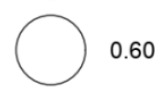

August 2018

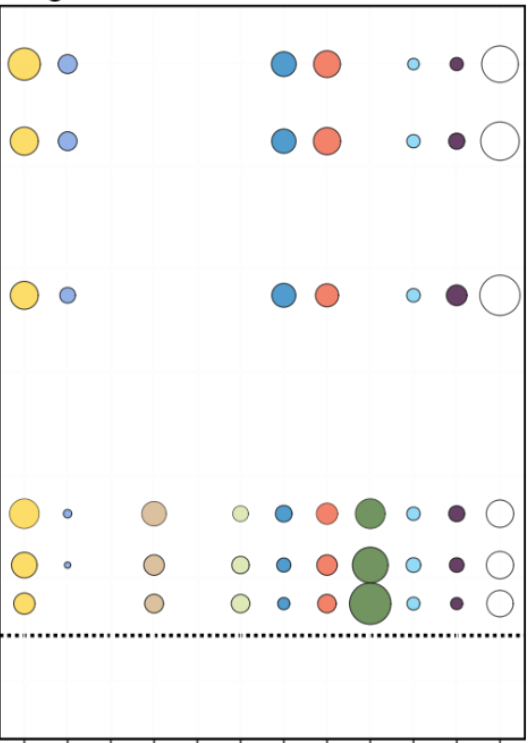

FFT/ water interface

Figure 4. Relative abundance of bacterial dominant orders, detected by Illumina sequencing of $16 \mathrm{~S}$ rRNA gene amplicons, for the Base Mine Lake water cap (summer 2016-2018) and FFT water interface (2016, 2017).

Further shifts reflect rapid responses by the microbial community to post alum changes in important e- donors and e- acceptors, which variably limited or enabled the required ecological niches. Taxa belonging to the order Frankiales, which are known to include those capable of nitrate reduction [49], were restricted to the water column and decreased in abundance in 2018, consistent with the marked absence of detectable nitrate concentrations in the 2018 BML water column (Figure 4). Groups related to methanotrophic isolates [50], such as Methylococcales, decreased in abundance and distribution, with apparent restriction to the bottom waters only (Table 1, Figure 4) coincident with the 
observed decrease in water cap dissolved methane concentrations post alum (Table 1). In contrast, Bacteroidales, restricted to the reducing conditions associated with FFT, pre alum, colonized the water column when anoxic/euxinic conditions occurred post alum, indicating its ability to migrate into the water cap once oxygen was depleted (Figure 4, Table 1). Similarly, Desulfuromonadales also migrated out of the surficial FFT, extending its presence into the newly anoxic, sulfate-rich bottom waters that occurred post alum (Figure 4). Mainly comprising Geobacter affiliates, their migration into these anoxic waters is consistent with the demonstrated functional capabilities of dissimilatory metal and sulfur reduction in hydrocarbon-contaminated sediments using the wide range of monomers shown for isolates of this genus [51]. Even though originally considered strict anaerobes, members of this group are also capable of microaerobic growth [52], enabling them to extend beyond the anoxic into hypoxic BML bottom waters after the addition of alum (Table 1). In contrast, Desulfobacterales was confined exclusively to the FFT, which may reflect its preference for fermentation products via sulfate reduction [53], which may be limited in the newly anoxic waters, and/or their potentially stricter anaerobic requirements. Interestingly, known relatives are capable of benzene degradation, i.e., more recalcitrant organic carbon compounds, under methanogenic conditions [54], suggesting that this order may play an important role in the later development of the lake. The results provided here are some of the first to document changes in microbial communities, post alum addition, and illuminate the rapidity with which microorganisms will respond to perturbations that change environmental characteristics.

\subsection{Improved Clarity and Biogeochemical Consequences in $B M L$}

While absolute concentrations of TOC/DOC would classify BML as a meso-eutrophic system across all three sampling years, organic carbon pools in BML are largely dominated by recalcitrant, complex organic carbon moieties associated with the bitumen extraction of oil sands [5], which would overwhelm the likely small, but important increases in autochthonous organic carbon that were suggested to occur by the collective geochemical and microbial community results, post alum. While all carbon concentrations decreased post alum, suggesting physical stripping out had occurred; the relative proportion of organic to total carbon decreased post alum across the water cap, with the relative \% decrease being the highest for hypolimnetic TOC and DOC relative to TC concentrations (36\% and 31\%, respectively; Table 2). These results suggest that greater degradation and thus decreased organic carbon occurred post alum addition. The stimulation of autochthonous organic carbon is supported by the increased Secchi disk depths, epilimnetic oxygen concentrations, Chla concentrations and periphyton abundance observed in 2017 and 2018 (Figure S2). These new autochthonous food web sources of more degradable organic carbon would, in turn, support greater rates of decomposition and heterotrophic microbial biomass. For instance, members of Verrucomicrobiales became dominant after the alum addition, consistent with their ability to degrade chitin [55], an important constituent of zooplankton, such as the Daphnia pulex exoskeleton, animals that also increased in abundance post alum (data not shown).

Changes in phospholipid fatty acid (PLFA) concentrations and profiles consistent with this scenario also occurred, as described in more detail in Slater et al. [56]. Specifically higher PLFA concentrations and increased autotrophic PLFA abundance (i.e., C18:1 unsaturated, polyunsaturated), as well as $\delta^{13} \mathrm{C}$ values of PLFA consistent with autotrophy, collectively indicate the establishment of an epilimnetic phototrophic microbial community post alum. Transport of organic biomass to the hypolimnion, hypothesized here to drive the initiation of anoxic conditions observed post alum, is reflected in the recognizable signature of the phototrophic (epilimnetic) communities (increased C18:1 and polyunsaturated PLFA) in hypolimnetic samples post alum.

Furthermore, 2018 PLFA distributions continued to indicate the presence of an epilimnetic phototrophic community, though at lower abundances than in 2017, as well as the downward transport of this algal biomass into the hypolimnion (higher phototrophic 
PLFA abundance). However, in contrast to 2017, in 2018, there was a notable increase in branched and cyclic PLFA, particularly in the hypolimnion. Branched PLFA are generally associated with heterotrophic microbial communities, suggesting the greater establishment of heterotrophy in the bottom waters of BML by 2018. Stable isotopic compositions $\left(\delta^{13} \mathrm{C}\right)$ of PLFA in 2018 showed some of the largest changes over the four-year interval studied in Slater et al. [56]. Most notably, there was a convergence of epilimnetic $\delta^{13} \mathrm{C}$ of PLFA in August 2018 to that observed in May 2017, consistent with the establishment of a phototrophic community two years post alum addition. The observed negative shift in $\delta^{13} \mathrm{C}$ of PLFA in the 2018 August hypolimnion is consistent with the greater contributions of anaerobic metabolism to the microbial PLFA pool.

\section{Conclusions}

The whole lake alum amendment, trialed in BML to clarify the lake through tailings sequestration, achieved this objective, as observed in increased Secchi disk depths in 2017 and 2018. It also resulted in increased autochthonous carbon production, evidenced by increased Chla, periphyton biomass and epilimnetic oxygen concentrations in the two August sampling periods post alum addition. However, hypolimnetic anoxia also occurred, contrasting with the observed oxygen outcomes of alum treatment in eutrophying lakes [24]. The results observed in BML reflect the significant differences in the sources of oxygenconsuming constituents (OCC) in these two types of systems. The major oxygen-consuming process in eutrophic lakes is the decomposition of abundant biomass material generated by excess nutrient loads. Thus, in a eutrophic lake, alum increases the overall oxygen concentrations in the water column by reducing nutrients, biomass generation (major reductant) and oxygen consumption. Prior to alum addition, BML water cap oxygen consumption was primarily driven by the mobilization of reductants from the underlying FFT layer, and its organic carbon pool was dominated by recalcitrant organic moieties, i.e., easily degraded organic carbon was highly limited and its contribution to overall oxygen consumption minimal (Figure 5).

The increased oxygen consumption associated with aerobic degradation of this new biomass source induced anoxia and enabled anaerobic biogeochemical cycling directly within the BML water cap post alum. Rapid interlinked structural and functional changes in the microbial community, important to biogeochemical cycling and overall oxygen status of BML, occurred in response (Figure 5). Specifically, microbial groups associated with labile organic carbon processing appeared (i.e., SAR11-LD12 subclade); specialist groups such as MBAE14, associated with carbon-limited, ammonia-rich restricted niches that existed in BML prior to alum addition [14], disappeared; and the SRB group Desulfuromonodales appeared (Figures 4 and 5).

Enabling SRB activity directly within the water cap-where sulfate concentrations are high ( 2 $\mathrm{mM})$-is likely to exacerbate oxygen consumption, as the oxygen-driven oxidation of sulfide, abiotically and/or biotically, will be rapid under BML geochemical conditions. Ultimately, the developmental trajectory of BML water cap oxygen status-i.e., the spatial and temporal extent of anoxia-will now reflect the balance between oxygen inputs associated with epilimnetic primary production and physical mixing processes, and this expanded set of oxygen consumption processes of biomass degradation, sulfide oxidation and on-going FFT reductant mobilization (Figure 5). The results here identify the need to fully understand the biogeochemical processes affecting oxygen concentrations and distribution in these engineered systems, such that the effects of potential treatment strategies can be accurately predicted. More broadly, these results contribute to our understanding of perturbation effects on microbial community structure and function in aquatic systems. 


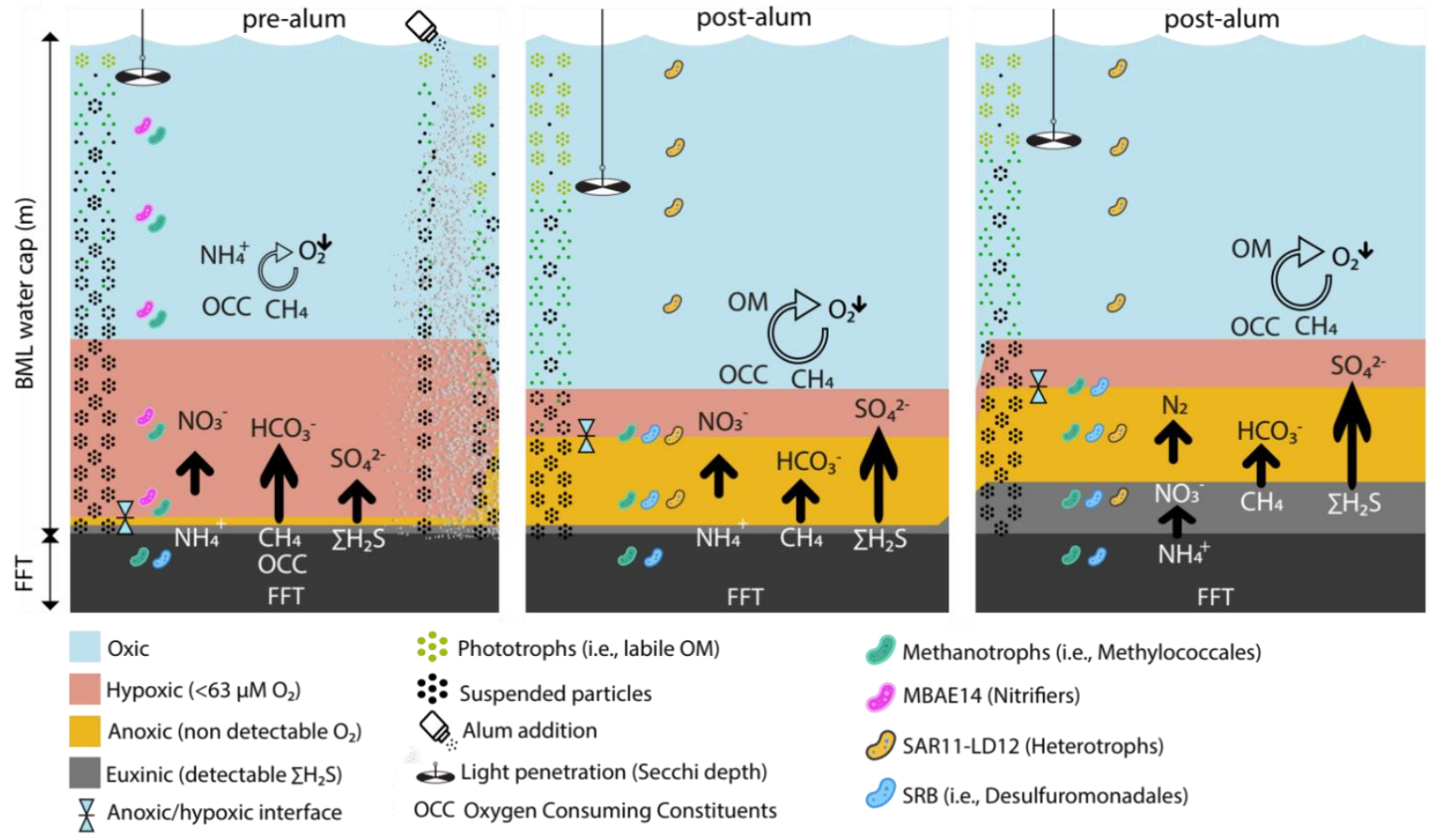

Figure 5. Schematic model depicting the biogeochemical trajectory impairing oxygen concentrations in BML resulting from alum addition. Prior to alum addition (2016), the major oxygen-consuming constituents were mobilized reductants from the underlying FFT layer. Alum addition in the fall of 2016 removed particles from the water cap, improving clarity and enabling greater primary production in 2017 and 2018. Increased oxygen consumption driven by the degradation of more abundant biomass affected oxygen status post alum with increased anoxia $(2017,2018)$, the upward migration of the anoxic-hypoxic interface and the generation of sulfide directly within the water cap.

Supplementary Materials: The following are available online at https:/ /www.mdpi.com/article/10 .3390 / microorganisms10030510/s1, Figure S1: Time series of changes in light penetration (Secchi disk depths). Figure S2: Total periphyton biomass for BML (28-day colonization experiment at peak boreal summer). Table S1: Organic phosphorus for BML. Table S2: Amplicon sequence variants diversity.

Author Contributions: L.A.W. initiated and planned the study. L.A.W., G.L.J., J.F.M., T.E.C.N. and M.B.J.L. conducted the field campaigns, G.L.J., L.-X.C. and J.F.B. performed microbiological analyses, G.F.S., T.E.C.N. and M.B.J.L. performed chemical analyses, and G.L.J., L.-X.C. and J.F.M. carried out bioinformatics and statistical analyses. All authors contributed to data analysis and the writing of the paper. All authors have read and agreed to the published version of the manuscript.

Funding: This research was funded by NSERC (CRDPJ 488301-15) and COSIA. Additional support came from The National Fund for Scientific and Technological Development of Chile (FONDECYT) Grant 11191138 (The National Research and Development Agency of Chile, ANID Chile), FONDECYT Grant 1200252 (ANID Chile) and COPAS COASTAL ANID FB210021 to G.L.J.

Institutional Review Board Statement: Not applicable.

Informed Consent Statement: Not applicable.

Data Availability Statement: Water column and FFT 16S rRNA gene amplicon sequences are deposited at NCBI under Bioproject PRJNA552483.

Acknowledgments: We would like to thank Syncrude Canada Limited, Mine Closure Research Group for field sampling support, and especially Carla Wytrykush for her inputs to the development of this manuscript. We would also like to acknowledge the help provided by boat operators Christopher Beierling, Richard Kao, and Rocky Johnson and the BML coordinator Janna Lutz, the field laboratory 
manager Mohamed Salem and field leads Wendy Kline, John Arnold and Mike Arsenault on-site at Mildred Lake mine, Fort McMurray, AB. Thanks also to Sarah B. Rudderham, Florent Risacher, Patrick Morris and Daniel Arriaga for contributions to field sample collection and analyses, and Jennie Kirby in the Environmental Organic Geochemistry laboratory for her work supporting the methane concentration analysis.

Conflicts of Interest: The authors declare no conflict of interest. The funders had no role in the design of the study; in the collection, analyses, or interpretation of data; in the writing of the manuscript, or in the decision to publish the results.

\section{References}

1. Dompierre, K.A.; Lindsay, M.B.J.; Cruz-Hernández, P.; Halferdahl, G.M. Initial geochemical characteristics of fluid fine tailings in an oil sands end pit lake. Sci. Total Environ. 2016, 556, 196-206. [CrossRef] [PubMed]

2. Arriaga, D.; Nelson, T.C.; Risacher, F.F.; Morris, P.K.; Goad, C.; Slater, G.F.; Warren, L.A. The co-importance of physical mixing and biogeochemical consumption in controlling water cap oxygen levels in Base Mine Lake. Appl. Geochem. 2019, 111, 104442. [CrossRef]

3. Foght, J.M.; Gieg, L.M.; Siddique, T. The microbiology of oil sands tailings: Past, present, future. FEMS Microbiol. Ecol. 2017, 93, fix034. [CrossRef]

4. Kong, J.D.; Wang, H.; Siddique, T.; Foght, J.; Semple, K.; Burkus, Z.; Lewis, M.A. Second-generation stoichiometric mathematical model to predict methane emissions from oil sands tailings. Sci. Total Environ. 2019, 694, 133645. [CrossRef] [PubMed]

5. Siddique, T.; Kuznetsova, A. Linking hydrocarbon biodegradation to greenhouse gas emissions from oil sands tailings and its impact on tailings management. Can. J. Soil Sci. 2020, 100, 537-545. [CrossRef]

6. Alberta Energy Regulator. State of Fluid Tailings Management for Mineable Oil Sands, 2019; Alberta Energy Regulator: Calgary, AB, Canada, 2020.

7. Alberta Energy Regulator. Directive 085: Fluid Tailings Management for Oil Sands Mining Projects; Alberta Energy Regulator: Calgary, AB, Canada, 2016.

8. Simieritsch, T.; Obad, J.; Dyer, S. Tailings Performance Criteria and Requirements for Oil Sands Mining Schemes; Pembina Institute: Drayton Valley, AB, Canada, 2010.

9. Clearwater Environmental Consultants. End Pit Lakes Technical Guidance Document; Clearwater Environmental Consultants: Fort McMurray, AB, Canada, 2013; Volume 53.

10. Kabwe, L.K.; Scott, J.D.; Beier, N.A.; Wilson, G.W.; Jeeravipoolvarn, S. Environmental implications of end pit lakes at oil sand mines in Alberta, Canada. Environ. Geotech. 2019, 6, 67-74. [CrossRef]

11. Canada's Oil Sands Innovation Alliance. Pit Lakes: A Surface Mining Perspective: Tailings Environmental Priority Area (EPA); Canada's Oil Sands Innovation Alliance: Calgary, AB, Canada, 2021.

12. Risacher, F.F.; Morris, P.K.; Arriaga, D.; Goad, C.; Nelson, T.C.; Slater, G.F.; Warren, L.A. The interplay of methane and ammonia as key oxygen consuming constituents in early stage development of Base Mine Lake, the first demonstration oil sands pit lake. Appl. Geochem. 2018, 93, 49-59. [CrossRef]

13. Fisseha, B.; Wilson, G.W.; Simms, P. Assessment of Self-Weight Consolidation of Flocculated Fluid Fine Tailings under Various Environmental Conditions. Proceedings of the Paste 2018: 21st International Seminar on Paste and Thickened Tailings, 2018; Australian Centre for Geomechanics: Crawley, Australia, 2018; pp. 291-304.

14. Mori, J.F.; Chen, L.-X.; Jessen, G.L.; Rudderham, S.B.; McBeth, J.M.; Lindsay, M.B.J.; Slater, G.F.; Banfield, J.F.; Warren, L.A. Putative Mixotrophic Nitrifying-Denitrifying Gammaproteobacteria Implicated in Nitrogen Cycling Within the Ammonia/Oxygen Transition Zone of an Oil Sands Pit Lake. Front. Microbiol. 2019, 10, 2435. [CrossRef]

15. Tedford, E.; Halferdahl, G.; Pieters, R.; Lawrence, G.A. Temporal variations in turbidity in an oil sands pit lake. Environ. Fluid Mech. 2019, 19, 457-473. [CrossRef]

16. Clark, M.G.; Drewitt, G.B.; Carey, S.K. Energy and carbon fluxes from an oil sands pit lake. Sci. Total Environ. 2021, 752, 141966. [CrossRef]

17. Syncrude. Base Mine Lake Monitoring and Research Summary Report: Results from 2013-2018; Syncrude: Fort McMurray, AB, Canada, 2019.

18. Huser, B.J.; Egemose, S.; Harper, H.; Hupfer, M.; Jensen, H.; Pilgrim, K.M.; Reitzel, K.; Rydin, E.; Futter, M. Longevity and effectiveness of aluminum addition to reduce sediment phosphorus release and restore lake water quality. Water Res. 2016, 97, 122-132. [CrossRef] [PubMed]

19. Özkundakci, D.; Hamilton, D.; Scholes, P. Effect of Intensive Catchment and in-Lake Restoration Procedures on Phosphorus Concentrations in a Eutrophic Lake. Ecol. Eng. 2010, 36, 396-405. [CrossRef]

20. Galvez-Cloutier, R.; Saminathan, S.K.M.; Boillot, C.; Triffaut-Bouchet, G.; Bourget, A.; Soumis-Dugas, G. An evaluation of several in-lake restoration techniques to improve the water quality problem (eutrophication) of Saint-Augustin Lake, Quebec, Canada. Environ. Manag. 2012, 49, 1037-1053. [CrossRef] [PubMed]

21. Gelda, R.K.; Effler, S.W.; Peng, F. Modeling Turbidity and the Effects of Alum Application for a Water Supply Reservoir. J. Environ. Eng. 2012, 138, 38-47. [CrossRef] 
22. Diemert, S.; Andrews, R. The impact of alum coagulation on pharmaceutically active compounds, endocrine disrupting compounds and natural organic matter. Water Sci. Technol. Water Supply 2013, 13, 1348. [CrossRef]

23. Nogaro, G.; Burgin, A.J.; Schoepfer, V.A.; Konkler, M.J.; Bowman, K.L.; Hammerschmidt, C.R. Aluminum sulfate (alum) application interactions with coupled metal and nutrient cycling in a hypereutrophic lake ecosystem. Environ. Pollut. 2013, 176, 267-274. [CrossRef]

24. Huser, B.J.; Futter, M.; Lee, J.T.; Perniel, M. In-lake measures for phosphorus control: The most feasible and cost-effective solution for long-term management of water quality in urban lakes. Water Res. 2016, 97, 142-152. [CrossRef]

25. Steinman, A.D.; Ogdahl, M.E. Macroinvertebrate response and internal phosphorus loading in a Michigan Lake after alum treatment. J. Environ. Qual. 2012, 41, 1540-1548. [CrossRef]

26. Rönicke, H.; Frassl, M.A.; Rinke, K.; Tittel, J.; Beyer, M.; Kormann, B.; Gohr, F.; Schultze, M. Suppression of bloom-forming colonial cyanobacteria by phosphate precipitation: A 30 years case study in Lake Barleber (Germany). Ecol. Eng. 2021, 162, 106171. [CrossRef]

27. Wang, X.; Li, W.; Xiao, Y.; Cheng, A.; Shen, T.; Zhu, M.; Yu, L. Abundance and diversity of carbon-fixing bacterial communities in karst wetland soil ecosystems. CATENA 2021, 204, 105418. [CrossRef]

28. Zhang, B.; Wei, Z.; Schaeffer, S.M.; Liang, A.; Ding, X. Recovery of bacterial communities and functions of soils under ridge tillage and no-tillage after different intensities and frequencies of drying-wetting disturbances in agroecosystems of northeastern China. CATENA 2021, 203, 105367. [CrossRef]

29. Allison, S.D.; Martiny, J.B.H. Colloquium paper: Resistance, resilience, and redundancy in microbial communities. Proc. Natl. Acad. Sci. USA 2008, 105, 11512-11519. [CrossRef] [PubMed]

30. Shade, A.; Peter, H.; Allison, S.; Baho, D.; Berga, M.; Buergmann, H.; Huber, D.; Langenheder, S.; Lennon, J.; Martiny, J.; et al Fundamentals of Microbial Community Resistance and Resilience. Front. Microbiol. 2012, 3, 417. [CrossRef] [PubMed]

31. Francis, D.J.; Barbour, S.L.; Lindsay, M.B.J. Ebullition enhances chemical mass transport across the tailings-water interface of oil sands pit lakes. J. Contam. Hydrol. 2022, 245, 103938. [CrossRef] [PubMed]

32. Dompierre, K.A.; Barbour, S.L. Thermal properties of oil sands fluid fine tailings: Laboratory and in situ testing methods. Can. Geotech. J. 2017, 54, 428-440. [CrossRef]

33. Whaley-Martin, K.J.; Chen, L.-X.; Nelson, T.C.; Gordon, J.; Kantor, R.; Twible, L.E.; Marshall, S.; Rossi, L.; Bessette, B.; Baron, $\mathrm{C}$; ; et al. Acidity and sulfur oxidation intermediate concentrations controlled by $\mathrm{O}_{2}$-driven partitioning of sulfur oxidizing bacteria in a mine tailings impoundment. bioRxiv 2021. [CrossRef]

34. Bates, S.T.; Berg-Lyons, D.; Caporaso, J.G.; Walters, W.A.; Knight, R.; Fierer, N. Examining the global distribution of dominant archaeal populations in soil. ISME J. 2010, 5, 908. [CrossRef]

35. Caporaso, J.G.; Lauber, C.L.; Walters, W.A.; Berg-Lyons, D.; Lozupone, C.A.; Turnbaugh, P.J.; Fierer, N.; Knight, R. Global patterns of 16S rRNA diversity at a depth of millions of sequences per sample. Proc. Natl. Acad. Sci. USA 2011, 108, 4516-4522. [CrossRef]

36. Caporaso, J.G.; Lauber, C.L.; Walters, W.A.; Berg-Lyons, D.; Huntley, J.; Fierer, N.; Owens, S.M.; Betley, J.; Fraser, L.; Bauer, M.; et al. Ultra-high-throughput microbial community analysis on the Illumina HiSeq and MiSeq platforms. ISME J. 2012, 6, 1621-1624. [CrossRef]

37. Martin, M. Cutadapt removes adapter sequences from high-throughput sequencing reads. EMBnet. J. 2011, 17, 10. [CrossRef]

38. Callahan, B.J.; McMurdie, P.J.; Rosen, M.J.; Han, A.W.; Johnson, A.J.A.; Holmes, S.P. DADA2: High-resolution sample inference from Illumina amplicon data. Nat. Methods 2016, 13, 581-583. [CrossRef]

39. Quast, C. The SILVA ribosomal RNA gene database project: Improved data processing and web-based tools. Nucleic Acids Res. 2013, 41, 590-596. [CrossRef] [PubMed]

40. Buttigieg, P.L.; Ramette, A. A guide to statistical analysis in microbial ecology: A community-focused, living review of multivariate data analyses. FEMS Microbiol. Ecol. 2014, 90, 543-550. [CrossRef] [PubMed]

41. Ramette, A. Multivariate analyses in microbial ecology. FEMS Microbiol. Ecol. 2007, 62, 142-160. [CrossRef] [PubMed]

42. Oksanen, J.; Blanchet, G.; Kindt, R.; Legendre, P.; O’Hara, B. Vegan: Community Ecology Package, version 1.17-4; 2010. Available online: https://www.researchgate.net/publication/264237828_H2010_Vegan_Community_Ecology_Package_R_package_ version_117-4 (accessed on 10 January 2022).

43. Rudderham, S.B. Geomicrobiology and Geochemistry of Fluid Fine Tailings in an Oil Sands End Pit Lake; University of Saskatchewan: Saskatoon, SK, Canada, 2019.

44. Lin, Q.; Fan, M.; Peng, X.; Ma, J.; Zhang, Y.; Yu, F.; Wu, Z.; Liu, B. Response of Vallisneria natans to aluminum phytotoxicity and their synergistic effect on nitrogen, phosphorus change in sediments. J. Hazard. Mater. 2020, 400, 123167. [CrossRef] [PubMed]

45. Yeboah, D.; Kingston, S. Tree species richness decreases while species evenness increases with disturbance frequency in a natural boreal forest landscape. Ecol. Evol. 2016, 6, 842-850. [CrossRef]

46. Klann, J.; McHenry, A.; Montelongo, C.; Goffredi, S. Decomposition of plant-sourced carbon compounds by heterotrophic betaproteobacteria isolated from a tropical Costa Rican bromeliad. Microbiologyopen 2016, 5, 479-489. [CrossRef]

47. Chen, L.-X.; Zhao, Y.; McMahon, K.D.; Mori, J.; Jessen, G.L.; Nelson, T.C.; Warren, L.A.; Banfield, J.F. Wide Distribution of Phage That Infect Freshwater SAR11 Bacteria. mSystems 2021, 4, e00410-e00419. [CrossRef]

48. Bernardet, J.; Bowman, J.P. The Genus Flavobacterium. In The Prokaryotes; Springer: Berlin/Heidelberg, Germany, 2006; ISBN 0387307478 
49. Tamura, T.; Rainey, S. 41 The Family Sporichthyaceae. In The Prokaryotes; Springer: Berlin/Heidelberg, Germany, $2014 ;$ pp. 883-888. [CrossRef]

50. Smith, G.J.; Angle, J.C.; Solden, L.M.; Borton, M.A.; Morin, T.H.; Daly, R.A.; Johnston, M.D.; Stefanik, K.C.; Wolfe, R.; Gil, B.; et al. Members of the Genus Methylobacter Are Inferred To Account for the Majority of Aerobic Methane Oxidation in Oxic Soils from a Freshwater Wetland. MBio 2018, 9, e00815-e00818. [CrossRef]

51. Caccavo, F.; Lonergan, D.J.; Lovley, D.R.; Davis, M.; Stolz, J.F.; McInerney, M.J. Geobacter sulfurreducens sp. nov., a hydrogenand acetate-oxidizing dissimilatory metal-reducing microorganism. Appl. Environ. Microbiol. 1994, 60, 3752-3759. [CrossRef]

52. Engel, C.E.A.; Vorländer, D.; Biedendieck, R.; Krull, R.; Dohnt, K. Quantification of microaerobic growth of Geobacter sulfurreducens. PLoS ONE 2020, 15, e0215341. [CrossRef] [PubMed]

53. Dyksma, S.; Lenk, S.; Sawicka, J.E.; Mußmann, M. Uncultured Gammaproteobacteria and Desulfobacteraceae Account for Major Acetate Assimilation in a Coastal Marine Sediment. Front. Microbiol. 2018, 9, 3124. [CrossRef] [PubMed]

54. Noguchi, M.; Kurisu, F.; Kasuga, I.; Furumai, H. Time-resolved DNA stable isotope probing links Desulfobacterales- and Coriobacteriaceae-related bacteria to anaerobic degradation of benzene under methanogenic conditions. Microbes Environ. 2014, 29, 191-199. [CrossRef] [PubMed]

55. Cabello-Yeves, P.J.; Ghai, R.; Mehrshad, M.; Picazo, A.; Camacho, A.; Rodriguez-Valera, F. Reconstruction of diverse verrucomicrobial genomes from metagenome datasets of freshwater reservoirs. Front. Microbiol. 2017, 8, 2131. [CrossRef]

56. Slater, G.F.; Goad, C.A.; Lindsay, M.B.J.; Mumford, K.G.; Colenbrander Nelson, T.E.; Brady, A.L.; Jessen, G.L.; Warren, L.A. Isotopic and Chemical Assessment of the Dynamics of Methane Sources and Microbial Cycling during Early Development of an Oil Sands Pit Lake. Microorganisms 2021, 9, 2509. [CrossRef] 